Helper, Vol 34 No 2 (2017) - 9

\title{
IMPLEMENTASI PROGRAM BIMBINGAN DAN KONSELING BAGI ANAK BERKEBUTUHAN KHUSUS (ABK) DI SMP NEGERI 32 SURABAYA
}

\author{
Lutfi Isni Badiah \\ Prodi Pendidikan Khusus UNIPA Surabaya \\ Email: lutfiisnibadiah@gmail.com
}

\begin{abstract}
Abstrak
Tujuan dalam penelitian ini adalah untuk mendeskripsikan: (1) pelaksanaan program BK bagi $A B K$ di sekolah inklusi SMP Negeri 32 Surabaya, (2) pendekatan yang digunakan, (3) hambatan yang dihadapi, serta (4) solusi yang dilakukan untuk mengatasi hambatan yang dihadapi. Sumber data dalam penelitian terdiri dari: guru bimbingan dan konseling; kepala SMP Negeri 32 Surabaya; wali kelas, guru pendamping khusus (GPK), dan koordinator pelaksanaan dan inklusi. Subjek primer dalam penelitian ini adalah guru bimbingan dan konseling. Jenis penelitian ini merupakan penelitian lapangan (field research). Teknik pengumpulan data melalui observasi, wawancara, dokumentasi. Dari hasil penelitian diperoleh data yakni: kurikulum untuk ABK yang digunakan di SMP Negeri 32 Surabaya adalah kurikulum 2013 yang dimodifikasi sesuai dengan kemampuan dan kebutuhan $A B K$ dengan panduan dari hasil need asesment. Metode yang digunakan guru BK pada umumnya sama dengan siswa normal, hanya saja pelaksanaannya sedikit berbeda. Guru menggunakan metode ceramah, metode tanya jawab dan metode tutor sebaya. Hambatan yang dihadapi dalam pelaksanaan program BK bagi ABK di sekolah inklusi SMP Negeri 32 Surabaya mencakup (1) ciri khas/karakteristik siswa, (2) sikap dan konsentrasi belajar, (3) mengelola bahan ajar/media, (4) kurangnya pengetahuan dan keterampilan guru, (5) kurikulum sekolah, (6) sarana dan prasarana. Solusi yang dilakukan untuk mengatasi hambatan yang dihadapi adalah: (1) melakukan studi banding dengan sekolah lain yang juga menerima siswa berkebutuhan khusus, (2) memanfaatkan ajang musyawarah guru BK, (3) rutin mengirim guru untuk mengikuti pelatihan/seminar, (4) menjalin kerjasama dengan psikolog atau dengan guru pendidikan luar biasa.
\end{abstract}

Kata kunci : Anak Berkebutuhan Khusus, Bimbingan dan Konseling, Sekolah Inklusi

Pendahuluan

Anak berkebutuhan khusus seringkali mendapatkan hambatan, kesulitan dan masalah sebagai dampak keluarbiasaannya. Dampak yang dirasakan berupa hambatan aktivitas sehari-hari dan pembatasan beraktivitas di lingkungannya. Untuk mengatasi hal 
ini perlu adanya pemberian bantuan terhadap $\mathrm{ABK}$ agar mereka mampu berkembang. Bantuan yang diberikan tentunya fokus pada pengembangan kepribadian dan keterampilan hidup bagi ABK.

Salah satu cara untuk pengembangan kepribadian dan keterampilan hidup bagi $\mathrm{ABK}$ adalah melalui pendidikan. Sekolah mempunyai peranan yang penting untuk memberikan bekal ABK agar mampu berkembang dan berhasil dalam hidup bermasyarakat. Sehingga stigma negatif bahwa ABK merupakan beban bagi masyarakat dapat terhapuskan. Sebagai mana yang dikemukakan oleh Suhari dan Purwanta dalam Aisyah (2014), bahwa keberhasilan ABK dalam proses perkembangannya terlihat ketika mereka mampu berperan di masyarakat sesuai dengan derajat hambatannya. Salah satu cara sekolah mengembangkan kepribadian dan keterampilan hidup adalah dengan menyediakan layanan bimbingan dan konseling. Tujuan adanya layanan ini adalah agar ABK dapat mengoptimalkan perkembangan dan potensinya.
Dewasa ini, kesempatan ABK untuk memperoleh pendidikan bertambah luas seiring dengan diperkenalkannya sekolah inklusi. Sekolah inklusi merupakan sekolah yang menerima siswa ABK untuk belajar bersama dengan siswa normal. Sehingga tidak ada alasan lagi bahwa ABK tidak bisa bersekolah karena jauh dengan sekolah luar biasa (SLB). Program bimbingan dan konseling bagi ABK baik pada pendidikan inklusi maupun pendidikan segregasi difokuskan pada intervensi pengembangan perilaku adaptif, konseling keluarga, dan bahkan persiapan yang terkait dengan kemungkinan $\mathrm{ABK}$ memasuki kehidupan masyarakat atau dunia kerja. Namun sayangnya, menurut Sunardi (2005), pelaksanaan program BK di sekolah belum terlaksana secara sistematis dan intensif, meski sebenarnya guru pendamping khusus (GPK) dan guru BK sudah memahami urgensi layanan BK dalam proses keberhasilan $\mathrm{ABK}$.

Sekolah Menengah Pertama (SMP) Negeri 32 Surabaya merupakan salah satu sekolah yang menyelenggarakan 
pendidikan inklusi bagi ABK. Siswa ABK yang berada di SMPN 32 Surabaya terdiri dari siswa dengan gangguan intelektual dan siswa dengan autis. Berdasarkan uraian di atas, maka peneliti tertarik untuk meneliti bagaimana implementasi program $\mathrm{BK}$ bagi $\mathrm{ABK}$ di sekolah inklusi SMP Negeri 32 Surabaya. Tujuan dalam penelitian ini adalah untuk mendeskripsikan: (1) implementasi program BK bagi $\mathrm{ABK}$ di sekolah inklusi SMP Negeri 32 Surabaya, (2) pendekatan yang digunakan dalam program $\mathrm{BK}$ bagi $\mathrm{ABK}$ di sekolah inklusi SMP Negeri 32 Surabaya, (3) Hambatan yang dihadapi dalam pelaksanaan program $\mathrm{BK}$ bagi ABK di sekolah inklusi SMP Negeri 32 Surabaya, dan (4) Solusi yang dilakukan untuk mengatasi hambatan yang dihadapi dalam pelaksanaan program BK bagi ABK di sekolah inklusi SMP Negeri 32 Surabaya.

\section{Metode Penelitian}

Penelitian ini dilaksanakan di SMP Negeri 32 Surabaya dengan alasan bahwa sekolah ini merupakan salah satu penyelenggara sekolah inklusi. SMP
Negeri 32 Surabaya mempunyai siswa berkebutuhan khusus yang terdiri dari siswa dengan gangguan intelektual, slow learner, dan siswa autis yang tersebar di kelas X sampai XII. Subjek penelitian dipilih berdasarkan kriteria kesesuaian dengan tujuan penelitian (purposive sampling) agar menghasilkan data yang kredibel dan akurat. Dalam penelitian ini subjek penelitian terdiri dari: guru bimbingan dan konseling; kepala sekolah; wali kelas, dan koordinator pengelolaan dan inklusi. Namun yang menjadi subjek primer dalam penelitian ini adalah guru bimbingan dan konseling, sedangkan lainnya merupakan pelengkap. Jenis penelitian ini merupakan penelitian lapangan (field research). Teknik pengumpulan data menggunakan observasi, wawancara/interview, dan dokumentasi

\section{Hasil Penelitian}

Dari pelaksanaan penelitian yang telah dijelaskan di atas, diperoleh hasil penelitian sebagai berikut.

a. Implementasi program $\mathrm{BK}$ bagi $\mathrm{ABK}$ di sekolah inklusi SMP Negeri 32 Surabaya 
Berdasarkan hasil wawancara dengan guru BK di SMP Negeri 32 Surabaya, sebelum dilaksanakannya program BK, terlebih dahulu dilakukan perencanaan program BK. Diketahui bahwa siswa berkebutuhan khusus di SMP Negeri 32 Surabaya terdiri dari 16 ABK kelas VII, 14 ABK kelas VIII, dan 8 ABK kelas IX. Siswa berkebutuhan khusus di SMP Negeri 32 ini terdiri dari anak dengan lamban belajar (slow learner), anak dengan gangguan intelektual, serta anak denagan autisme. Sistem penerimaan siswa berkebutuhan khusus ini dilaksanakan bersama dengan siswa normal lainnya, dan tidak dibeda-bedakan. Hanya saja, untuk $\mathrm{ABK}$ dilakukan need asessment yang dilakukan oleh psikolog dan guru lulusan pendidikan luar biasa (PLB). Tujuan dilakukan need asessment untuk ABK ini agar guru dapat memetakan karakteristik dan kebutuhan ABK sehingga mempermudah guru memberikan pembelajaran dan pelayanan program BK yang tepat.
Proses need asesment ini dilakukan melalui instrumen checklist oleh tim asesment. Hal-hal yang digali dari kegiatan need asessment ini difokuskan pada: (1) Mengetahui kemampuan $\mathrm{ABK}$ melalui tes intelegensi, (2) Mengetahui kelebihan dan kekurangan tiap ABK, (3) Mengetahui hal yang disukai dan tidak disukai (apakah ABK mempunyai pantangan/alergi khusus) tiap ABK, (4) Wawancara dengan orang tua untuk memperoleh keterangan bagaimana kegiatan $\mathrm{ABK}$ di rumah. Hal ini penting dilakukan agar dapat menemukan keselarasan dengan program di sekolah. Dalam wawancara ini juga pihak sekolah meminta keseriusan dan komitmen orang tua terlibat dalam program yang telah disusun sekolah.

Pelaksanaan need asesment ini juga disertai dengan data pendukung dari luar seperti surat keterangan orang tua, riwayat kesehatan, surat rujukan dokter, dan lain-lain. Dari data tersebut, tim asesment kemudian mengolah dan menganalisis karakteristik ABK sekaligus membuat 
program layanan sesuai kebutuhan anak.

Kurikulum yang digunakan di SMP Negeri 32 Surabaya adalah kurikulum 2013. Hanya saja, untuk keperluan siswa berkebutuhan khusus, dilakukan modifikasi sesuai dengan kemampuan dan kebutuhan ABK. Modifikasi kurikulum ini diserahkan kepada masing-masing guru dengan panduan dari hasil need asesment. Psikolog, dan guru PLB. Kurikulum untuk ABK biasanya dimodifikasi pada aspek materi dan alokasi waktu. Untuk anak dengan gangguan intelektual dan slow learner diberikan alokasi waktu yang lebih panjang dan materi yang ringan. Sedangkan untuk anak dengan gangguan autis alokasi waktu sama, hanya materi yang diringkas. Perangkat pembelajaran untuk $\mathrm{ABK}$ juga mengalami modifikasi disesuaikan dengan kebutuhan ABK.

Jadwal pelaksanaan BK untuk ABK sesuai dengan jadwal yang telah disusun oleh sekolah. Agar siswa ABK dapat mencapai dan menguasi materi yang diberikan, maka penyampaian materi diberikan dalam dua bentuk, yakni:

1) Materi layanan bimbingan dan konseling diberikan secara penuh sebagaimana siswa reguler, jika siswa $\mathrm{ABK}$ dinilai mampu untuk menerima materi.

2) Materi yang diberikan kepada siswa ABK telah disesuaikan dengan kebutuhan masingmasing siswa. Artinya bahwa jika guru BK merasa materi yang ingin disampaikan terlalu berat, maka guru perlu menyederhanakan materi atau mengganti materi yang lain.

Pelaksanaan BK untuk siswa dengan slow learner, pelaksanaan pembelajaran dan layanan BK yang sifatnya klasikal umumnya cukup di ruang reguler (bersama siswa normal). Siswa dengan gangguan intelektual untuk umumnya dilaksanakan di ruang sumber dan di ruang reguler. Sedangkan untuk siswa dengan autis umumnya dilaksanakan di ruang sumber saja, tidak bersama dengan siswa normal. 
b. Pendekatan yang digunakan dalam program BK bagi $\mathrm{ABK}$ di sekolah inklusi SMP Negeri 32 Surabaya

Berdasarkan hasil wawancara yang dilakukan dengan guru BK, koordinator pengelolaan dan inklusi, serta guru kelas, peneliti dapat mengetahui bagaimana implementasi BK di SMP Negeri 32 ini. Untuk implementasi program bimbingan dan konseling bagi ABK di SMP Negeri 32 Surabaya menggunakan model kooperatif. Melalui model kooperatif ini siswa dan guru didorong untuk bekerjasama dalam melakukan tugas. Namun pihak sekolah juga membuat modifikasi pada aspek strategi, model pembelajaran, metode, dan media pembelajarannya untuk $\mathrm{ABK}$, sebagaimana dijelaskan di bawah ini.

1) Metode pemberian layanan $B K$ untuk $\mathrm{ABK}$

Metode yang digunakan guru BK pada umumnya sama dengan siswa normal, hanya saja pelaksanaannya sedikit berbeda. Ketika guru BK menyampaikan materi dengan metode ceramah di kelas yang terdapat anak dengan slow learner dan anak dengan gangguan intelektual, maka guru cenderung utuk mengulang keterangannya dan lebih banyak memfokuskan pada anak bermasalah. Berbeda dengan anak autis, guru perlu dibantu dengan guru pendamping khusus. Selain menggunakan metode ceramah, guru menggunakan metode tanya jawab untuk mengetahui dan mengukur sejauh mana pemahaman siswa tentang materi yang di sampaikan. Ketika guru menghadapi siswa slow learner dan siswa dengan gangguan intelektual guru bertanya secara pelan-pelan, menggunakan bahasa yang mudah dipahami, dan selalu mengulang kembali pertanyaannya.

Guru juga menggunakan metode tutor sebaya, yakni bekerja sama dengan siswa yang dapat menolong siswa lain. Hal ini dapat sekaligus memperkuat hubungan antar siswa di dalam kelas, meningkatkan empati antar siswa dan menciptakan suasana kelas yang lebih kondusif. Guru biasanya 
membagi siswa menjadi beberapa kelompok agar siswa saling bekerjasama dengan tetap melibatkan guru pendamping khusus dan wali kelas. Peran guru pendamping khusus ini adalah mengkondisikan siswa ABK. Jika siswa ABK menganggu kondisi kelas, maka guru pendamping khusus akan membawa ke ruang sumber.

2) Media yang digunakan dalam pelaksanaan BK

Guru juga menggunakan media ketika memberikan layanan BK kepada ABK. Pada umumnya media yang sering digunakan adalah media gambar dan video/VCD. Seperti mengenalkan jenis dan fungsi pekerjaan kepada ABK, guru lebih banyak menggunakan gambar jenis-jenis pekerjaan yang sering ditemui di masyarakat. Sebagai contoh gambar polisi, dokter, perawat, guru, pemadam kebakaran, penyanyi, dll. Media pembelajaran lain yang digunakan adalah media televisi dan video/VCD. Khusus bagi Siswa dengan autisme yag mempunyai kecenderungan hiperaktif, posisi duduknya diatur di bagian depan sehingga mempermudah guru untuk mengawasinya. Selain media di atas, guru juga dituntut untuk lebih kreatif dalam menggunakan media lain, sehingga siswa lebih tertarik dan mudah memahami materi yang disampaikan guru.

3) Evaluasi Layanan BK

Untuk mengetahui keberhasilan layanan $\mathrm{BK}$ untuk $\mathrm{ABK}$, setiap bulan guru BK mengevaluasi program BK. Hal ini dapat dilihat melalui jurnal kegiatan yang dibuat untuk setiap siswa ABK. Di dalam jurnal selalu dicantumkan masalah yang dihadapi dan solusi yang diberikan. Guru BK juga mengecek kepada guru kelas apakah di kelas, siswa ABK masih menunjukkan masalah yang sama. Jika metode dirasa belum berhasil menyelesaikan masalah, guru BK akan mengganti dengan metode lain. 
c. Hambatan yang dihadapi dalam pelaksanaan program $\mathrm{BK}$ bagi $\mathrm{ABK}$ di sekolah inklusi SMP Negeri 32 Surabaya

Hambatan yang sering dihadapi oleh guru bimbingan dan konseling pada siswa ABK disebabkan oleh banyak faktor yakni dijelaskan sebagai berikut.

1) Faktor Internal

a) Ciri Khas/Karakteristik Siswa Setiap ABK mempunyai karakteristik dan kebutuhan yang tersendiri. Hal ini membuat guru BK harus menyesuaikan materi, layanan dan kurikulum agar dapat mengakomodir setiap kebutuhan anak yang berbedabeda

b) Sikap dan Konsentrasi Belajar SMP Negeri 32 Surabaya mempunyai siswa dengan autisme yang cenderung hiperaktif. Siswa ini seringkali keluar masuk pada saat jam pelajaran berlangsung. Sedangkan siswa dengan gangguan intelektual jika merasa bosan justru lebih suka tidur dalam kelas. Hal ini membuat kelas kurang kondusif dan membuat guru BK dan guru kelas mengalami kewalahan ketika menghadapi siswa tersebut. Karenanya guru BK dan guru kelas memerlukan guru pendamping khusus yang bertugas mengkondisikan siswa ABK.

c) Mengelola Bahan Ajar/Media Guru BK seringkali mengalami kesulitan membuat atau menyediakan media yang tepat bagi ABK. Karena tidak jarang setiap memberikan layanan BK, guru harus menyediakan bermacammacam media untuk ABK agar tertarik dan tidak bosan.

2) Faktor-faktor Eksternal Belajar:

a) Faktor Guru

Baik guru BK maupun guru kelas seringkali mengeluhkan mengenai kurangnya pengetahuan dan keterampilan dalam menghadapi siswa ABK. Seringkali setiap proses 
pembelajaran dan proses layanan BK, selalu melibatkan psikolog dan guru pendamping khusus untuk membantu dan mengkondisikan siswa ABK.

b) Kurikulum Sekolah

SMP Negeri 32 belum mempunyai kurikulum khusus untuk ABK. Selama ini kurikulum untuk $\mathrm{ABK}$ adalah kurikulum yang dimodifikasi. Karena kurangnya tenaga dan pengetahuan guru, maka seringkali kurikulum modifikasi ini belum dapat menyeluruh mencakup kebutuhan masingmasing siswa ABK.

c) Sarana dan Prasarana

Di SMP Negeri 32 Surabaya hanya mempunyai 1 ruang sumber dan 1 ruang $\mathrm{BK}$. Sedangkan guru pendamping khusus hanya ada dua orang, dan psikolog 2 orang. Hal ini dirasakan kurang jika karena belum mencukupi kebutuhan siswa ABK yang berjumlah 38 siswa ABK. d) Solusi yang dilakukan untuk mengatasi hambatan yang dihadapi dalam pelaksanaan program $\mathrm{BK}$ bagi $\mathrm{ABK}$ di sekolah inklusi SMP Negeri 32 Surabaya

Untuk menghadapi permasalahan yang dikemukakan di atas, pihak sekolah berusaha untuk menemukan solusi tersebut. Beberapa solusi yang dilaksanakan oleh pihak sekolah adalah:

a) Pihak sekolah melakukan studi banding dengan sekolah lain yang juga menerima siswa berkebutuhan khusus.

b) Memanfaatkan ajang musyawarah guru BK yang rutin dilakukan sebulan sekali. Hal ini dimanfaatkan oleh guru untuk bertukar pikiran bagaimana cara menghadapi dan membantu siswa berkebutuhan khusus.

c) Rutin mengirim guru untuk mengikuti pelatihan/seminar 
yang berhubungan dengan

pelaksanaan bimbingan

konseling dan anak

berkebutuhan khusus.

Menjalin kerjasama dengan psikolog atau dengan guru pendidikan luar biasa terkait penanganan dan pemberian terapi kepada anak berkebutuhan khusus.

\section{Pembahasan Hasil Penelitian}

Dari penyajian data diatas, penulis dapat menganalisa bahwa penggunaan kurikulum 2013 untuk siswa ABK sudah cukup baik, karena kurikulum tersebut telah dimodifikasi dan disesuaikan dengan kebutuhan ABK. Sedangkan metode ketika pelaksanaan bimbingan dan konseling untuk siswa $A B K$ juga telah disesuaikan dengan tingkat kemampuan dan kecerdasan yang dimiliki oleh siswa ABK. Guru telah menggunakan pola komunikasi yang diulang-ulang dan pelan-pelan ketika berhadapan dengan siswa dengan gangguan intelektual dan slow learner. Hal ini sangat berguna bagi ABK untuk tetap bisa menerima materi sebagimana siswa pada umumnya meskipun dengan kemampuan dan kecerdasan di bawah rata-rata tidak semua materi dapat diterima secara tuntas karena kemampuannya yang terbatas. Menurut peneliti, penggunaan metode ini memang harus disesuaikan dengan karakteristik dan kebutuhan siswa $\mathrm{ABK}$, dam bukan sebaliknya. Jika siswa $\mathrm{ABK}$ yang "dipaksa" untuk mengikuti pola siswa normal, mala siswa ABK akan mengalami kegagalan dalam beradaptasi karena kelainan yang dialami.

Untuk membentuk sebuah sistem pendidikan yang tepat bagi siswa $\mathrm{ABK}$ memang harus dipersiapkan dengan baik. Perbandingan jumlah guru pendamping khusus di SMP Negeri 32 Surabaya yang hanya dua orang dengan jumlah siswa ABK yang berjumlah 32 dirasa kurang memadai. Terutama jika siswa ABK ini adalah siswa yang memerlukan pendampingan penuh dari guru pendamping khusus. Untuk mengakali hal ini, maka pihak sekolah mengirimkan guru reguler untuk mengikuti pelatihanpelatihan atau seminar tentang Pendidikan Luar Biasa (PLB) agar dapat pengetahuan tentang ABK. Sehingga 
diharapkan guru regular dapat menangani siswa $\mathrm{ABK}$ sendiri.

Agar pendidikan SMPN 32 Surabaya ini dapat terlaksana dengan baik, maka pihak sekolah perlu melibatkan semua pihak baik orang tua siswa, guru dan masyarakat. Pihak sekolah perlu melakukan melakukan sosialisasi kepada masyarakat sekitar dan orang tua khususnya siswa ABK mengenai program-program sekolah, baik program yang telah dilaksanakan, maupun yang akan dilaksanakan. Hal ini bertujuan agar masyarakat dan orang tua mendapat gambaran yang jelas tentang pelaksanaan sistem pendidikan di SMPN 32 Surabaya. Orang tua juga diharapkan dapat bekerjasama dengan guru kelas, guru mata pelajaran, maupun guru pembimbing khusus, sehingga pihak sekolah pun dapat mengetaui perkembangan anak di rumah.

\section{Kesimpulan Dan Saran Kesimpulan}

1. Kurikulum yang digunakan di SMP Negeri 32 Surabaya adalah kurikulum 2013. Hanya saja, untuk keperluan siswa berkebutuhan khusus, dilakukan modifikasi sesuai dengan kemampuan dan kebutuhan $\mathrm{ABK}$ dengan panduan dari hasil need asesment. Materi yang diberikan kepada siswa ABK telah disesuaikan dengan kebutuhan masing-masing siswa.

2. Metode yang digunakan guru BK pada umumnya sama dengan siswa normal, hanya saja pelaksanaannya sedikit berbeda. Guru menggunakan metode ceramah, metode tanya jawab dan metode tutor sebaya.

3. Hambatan yang dihadapi dalam pelaksanaan program $\mathrm{BK}$ bagi $\mathrm{ABK}$ di sekolah inklusi SMP Negeri 32 Surabaya mencakup (1) Ciri Khas/Karakteristik Siswa, (2) Sikap dan Konsentrasi Belajar, (3) Mengelola Bahan Ajar/Media, (4) Kurangnya pengetahuan dan keterampilan guru, (5) Kurikulum Sekolah, (6) Sarana dan Prasarana.

4. Solusi yang dilakukan untuk mengatasi hambatan yang dihadapi adalah: (1) melakukan studi banding dengan sekolah lain yang juga menerima siswa berkebutuhan khusus, (2) Memanfaatkan ajang 
musyawarah guru BK, (3) Rutin mengirim guru untuk mengikuti pelatihan/seminar, (4) Menjalin kerjasama dengan psikolog atau dengan guru pendidikan luar biasa.

\section{Saran}

1. Bagi Kepala Sekolah SMPN 32 Surabaya diharapkan dapat meningkatkan kualitas layanan bimbingan dan konseling dengan meningkatkan SDM guru, tidak hanya guru BK dan GPK saja, namun juga guru reguler.

2. Bagi guru hendaknya selalu mengembangkan keterampilan dan pengetahuan dalam memberikan layanan $\mathrm{BK}$ pada $\mathrm{ABK}$.

\section{DAFTAR PUSTAKA}

Aisyah, Umi. 2014. Strategi Layanan Bimbingan dan Konseling Bagi Siswa Tunanetra MTs Yaketunis Yogyakarta. Tesis. Pascasarjana UIN Sunan Kalijaga Yogyakarta

Budiyanto, dkk. 2009. Modul Training of Trainers Pendidikan Inklusif. Jakarta: Departemen Pendidikan Nasional Kartadinata (2008)

Baedowi, Ahmad. (2011). Inklusi. (online). Tersedia: http://www.kickandy.com/frien d/4/37/2092/re ad/Inklusi.html. (3 November 2011)
Dewanty, Cempaka Septyana. 2013.Guidance and Counseling Program Model At Junior School Inclusive Education Providers. Journal Mahasiswa Bimbingan dan Konseling. Volume 01 Nomor 01 Tahun 2013, 44-49 Januari 2013

Effendi, Mohammad. 2006. Pengantar Psikopedagogik Anak Berkelainan. Jakarta: Sinar Grafika Offset

Hidayat. 2009. Model dan Strategi Pembelajaran ABK dalam Setting Pendidikan Inklusif. Makalah disajikan dalam Workshop "Pengenalan \& Identifikasi Anak Berkebutuhan Khusus (ABK) \& Strategi Pembelajarannya" Balikpapan 25 Oktober 2009 Hotel Pacific

Kartadinata, Sunaryo. (2008). Alur Pikir Pendidikan Profesional Konselor dan Layanan Bimbingan dan Konseling Dalam Jalur Pendidikan Formal. Makalah disajikan pada Seminar Nasional oleh jurusan PPB FIP Unesa. Surabaya.

Marthan, Lay Kekeh. 2007. Manajemen Pendidikan Inklusif. Jakarta: Depdiknas Direktorat Jenderal Pendidikan Tinggi Direktorat Ketenagaan

Muhammad, Jamila K A. 2008. Special Education For Special Children. Jakarta: Hikmah

Slamet, Moh. Joko. 2016. Pelaksanaan Bimbingan dan Konseling Pada Peserta Didik Berkebutuhan Khusus di SMP Negeri Inklusi Kabupaten Sidoarjo. Jurnal BK. 
Volume 06 Nomor 02 Tahun 2016. UNESA Surabaya

Sukmadinata, Nana Saodih. 2007. Metode Penelitian Pendidikan. Jakarta: PT Remaja Rosdakarya.

Sunardi. 2005. Pedoman Pelaksanaan BP di SLB. Bandung; Pendidikan Luar Biasa Fakutas Ilmu Pendidikan Universitas Ilmu Pendidikan.

Wahyudi, Ari. 1998. Menggugah Kepedulian Masyarakat Terhadap Pendidikan Penyandang Cacat Melalui Pengembangan Model Penyuluhan Pendidikan. Jurnal Remediasi dan Rehabilitasi (JRR) tahun 8 No 19. 1998. 21-29

Wardani, I G A K, dkk. 2009. Pengantar Pendidikan Luar Biasa. Jakarta : Universitas Terbuka 
22 - Helper, Vol 34 No 2 (2017) 